\title{
Mean platelet component in non- proliferative and proliferative diabetic retinopathy
}

Arya Pradipta ${ }^{1}$, Angela Nurini Agni $^{1}$, Wasisdi Gunawan ${ }^{1}$, Muhammad Bayu Sasongko ${ }^{1}$, Tri Ratnaningsih ${ }^{2}$, Usi Sukorini ${ }^{2}$, Windarwati ${ }^{2}$, Ira Puspitawati ${ }^{2}$

${ }^{1}$ Department of Ophthalmology, Universitas Gadjah Mada, Sleman, Special Region of Yogyakarta, Indonesia; 'Department of Clinical Pathology, Universitas Gadjah Mada, Sleman, Special Region of Yogyakarta, Indonesia

\section{Abstract}

Introduction: Diabetic retinopathy (DR) remains a visually debilitating disease and is commonly classified according to its severity as non-proliferative DR (NPDR) or proliferative DR (PDR). Those suffering from PDR tend to have worse vascular complications and prognosis. Platelets exposed by vasculopathy caused by DR may be activated to try to maintain haemostasis. This activity can be illustrated by the mean platelet component (MPC). Therefore, by MPC monitoring we may be able to predict the progression from NPDR into PDR.

Purpose: To investigate the difference of MPC in patients with NPDR and PDR.

Study design: Cross-sectional.

Materials and methods: This study involved 71 DR patients. Preliminary data regarding the patients' demographic characteristics, diabetes history, related diseases, medication history, and general eye examination were recorded. Fundus photographs were taken after dilating eyedrops and DR was graded by an ophthalmologist. The patients were grouped into NPDR and PDR. Mean platelet component was analyzed using the automatic hematology analyzer ADVIA 120.

Results: Mean platelet component (MPC) was $26.69 \mathrm{~g} / \mathrm{dl}( \pm 1.79)$ and $25.52 \mathrm{~g} / \mathrm{dl}( \pm$ $1.20)$ in the NPDR and PDR group, respectively $(p=0.002)$, but was not clinically significant. In depth analysis into the DR grades differed significantly between mild NPDR and high-risk PDR $(p=0.015)$, and moderate NPDR and high-risk PDR ( $p=$ 0.024). Using our definition of mild DR (mild and moderate NPDR) and severe DR

Correspondence: Arya Pradipta. Jl. Bunga G6 Sawitsari Condongcatur Sleman, Yogyakarta, Indonesia.

E-mail: arya.prad.87@gmail.com 
(high-risk and advanced PDR), there was a significant difference with mean MPC of $27.01 \mathrm{~g} / \mathrm{dl}( \pm 1.64)$ and $25.31 \mathrm{~g} / \mathrm{dl}( \pm 1.22)$, respectively $(p=0.001)$. The proportion of activated platelets was also higher in severe DR. Negative correlations were found between MPC with duration of DM $(r=-0.333 ; p=0.004)$ and MPC with systolic blood pressure $(r=-0.241 ; p=0.043)$.

Conclusion: There was a significant difference in MPC between NPDR and PDR, but the results should be interpreted carefully. Further analysis between the mild and severe form of DR strengthened this finding.

Keywords: ADVIA 120, diabetic retinopathy, mean platelet component, non-proliferative diabetic retinopathy, platelet activation, proliferative diabetic retinopathy

\section{Purata komponen platelet diabetik retinopati bukan proliferatif dan proliferatif}

\section{Abstrak}

Pengenalan: Diabetik retinopati (DR) merupakan penyakit yang menyebabkan penurunan penglihatan dan sering diklasifikasi mengikut keterukan sebagai bukan proliferatif (NPDR) dan proliferatif (PDR). Pesakit PDR cenderung mengalami komplikasi vaskular dan prognosis yang lebih teruk. Platelet yang terdedah akibat vaskulopati yang disebabkan oleh DR boleh diaktifkan untuk pengekalan haemostasis dan ianya boleh dilihat dari nilai purata komponen platelet (MPC). Oleh itu, perkembangan NPDR ke PDR boleh diramal dengan pemantauan MPC. Tujuan: Untuk mengkaji perbezaan MPC dikalangan pesakit NPDR dan PDR. Rekabentuk kajian: Keratan rentas.

Material dan metodologi: Kajian ini melibatkan 71 orang pesakit DR. Data preliminari meliputi ciri demografi, sejarah diabetis, penyakit berkaitan, sejarah perubatan dan pemeriksaan umum okular direkodkan. Gambar fundus diambil selepas penggunaan ubat titis pengembangan mata dan ianya di gredkan kepada NPDR dan PDR oleh seorang Oftalmologis. Analisa MPC dilakukan menggunakan 'automatic hematology analyzer ADVIA 120'.

Keputusan: Nilai MPC adalah $26.69 \mathrm{~g} / \mathrm{dl}( \pm 1.79)$ untuk NDPR dan $25.52 \mathrm{~g} / \mathrm{dl}( \pm 1.20)$ untuk PDR $(p=0.002)$, tetapi tidak signifikan secara klinikal. Analisa selanjutnya terhadap gred DR menunjukkan perbezaan signifikan antara NDPR ringan dan PDR risiko-tinggi $(p=0.015)$ dan antara NDPR sederhana dan PDR risiko-tinggi $(\mathrm{p}=0.024)$. Perbezaan yang signifikan $(p=0.001)$ turut didapati apabila pesakit diklasifikasikan kepada DR ringan (NDPR ringan dan sederhana) dan DR teruk (PDR risiko-tinggi dan teruk). Nilai MPC untuk DR ringan adalah $27.01 \mathrm{~g} / \mathrm{dl}$ ( \pm 
1.64) dan untuk DR teruk adalah $25.31 \mathrm{~g} / \mathrm{dl}( \pm 1.22)$. Kadar pengaktifan platelet juga didapati lebih tinggi dalam DR teruk. Korelasi negatif diperolehi antara MPC dan tempoh DM $(r=-0.333 ; p=0.004)$ dan antara MPC dan tekanan darah sistolik $(r=$ $-0.241 ; p=0.043)$.

Kesimpulan: Terdapat perbezaan MPC yang signifikan antara NPDR dan PDR. Walaubagaimana pun keputusan ini perlu di interpretasi dengan teliti. Analisa selanjutnya antara DR ringan dan teruk mengukuhkan hasil kajian ini.

Katakunci: ADVIA 120, diabetik retinopati, diabetik retinopati bukan proliferatif, pengkatifan platelet, diabetik retinopati proliferatif, purata komponen platelet

\section{Introduction}

Diabetic retinopathy (DR) is a significant microvascular complication of diabetes mellitus (DM), which has a debilitating impact on vision and is the most frequent cause of blindness among adults aged 20-74 years. ${ }^{1}$ Globally, the number of DR cases is expected to rise from 126.6 million in 2010 to 191.1 million in 2030. ${ }^{2}$ The prevalence of DR among DM patients was reported to be from $27.8 \%{ }^{3}$ to $34.08 \%{ }^{4}$ Patients with DR carry the risk of progressing into vision-threatening diabetic retinopathy (VTDR) and approximately 56.3 million will suffer in 2030 if no proper management is undertaken. Those with VTDR have lower quality of life and are burdened with higher cost of treatment.

DR is mainly classified into two large groups: non-proliferative diabetic retinopathy group (NPDR) and proliferative diabetic retinopathy (PDR). Between these two groups, the latter is more severe and tends to cause more visual complications. Several known complications related to PDR are retinal detachment, vitreous hemorrhage, and glaucoma, which are rarely found on NPDR. Therefore, PDR warrants early detection and thorough management. ${ }^{5}$

Increase in platelet reactivity has been stated to be a risk factor for progression to PDR. For example, one parameter of the platelet activation index, mean platelet volume (MPV), was increased in PDR subjects in China. ${ }^{5}$ Another study also mentioned the role of platelet activation in inflammation, which worsened the state of DR. ${ }^{6}$ Platelets are anuclear discoid cells that circulate in the bloodstream and contribute to hemostasis by mainly plugging damaged blood vessels. When activated, such as by endothelial dysfunction caused by chronic hyperglycemia in DM, they will change shape, adhere to the subendothelial surface, form thrombi, and secrete aggregation factors. $^{7,8}$ In another study, platelet aggregation was reported to be higher in PDR subjects compared with NPDR and normal subjects, further showing the difference in platelet activation between these groups. ${ }^{9}$

Platelet activation can be measured with a practical and relatively inexpensive method using an automatic hematology analyzer. Compared to traditional platelet 
parameters such as MPV or platelet distribution width, mean platelet component (MPC) is considered the newer addition. ${ }^{8}$ The MPC value represents platelet density, and upon activation, it will decrease due to the release of platelet granule contents. ${ }^{10}$ Currently, there in no clinical guideline for using MPC in DM subjects with DR; therefore, evidence-based research is needed.

\section{Materials and methods}

\section{Subjects}

This study used a cross-sectional design, involving 71 subjects with DR during the study period at Dr. Sardjito General Hospital Yogyakarta from January to June 2018. The subjects were examined and their blood sampled to check for MPC density. The inclusion criteria were patients aged 30 years old or above, diagnosed with type 2 DM previously, with DR, willing to having their blood sampled, and who provided informed consent. Exclusion criteria for this study were subjects on antiplatelet therapy, subjects with coronary or congestive heart disease, subjects with deep vein thrombosis, rheumatoid arthritis, and chronic obstructive pulmonary disease, and subjects with 20 years of smoking history.

\section{Data collection}

Demographic and clinical data were taken prior to fundus photograph, including age, gender, DM history, related diseases, medication history, previous eye surgery, previous eye trauma, history of allergies, and general eye examination including visual acuity and anterior segment. From the fundus photographs, the subjects were classified as having NPDR or PDR and grouped accordingly. Blood sampling was performed and parameters such as $\mathrm{HbA1C}, \mathrm{CBC}, \mathrm{MPC}$, and other platelet parameters were examined at the Laboratory of Clinical Pathology, Faculty of Medicine, Universitas Gadjah Mada. The study followed the tenets of the Declaration of Helsinki. The Ethics Committee of the Faculty of Medicine, Universitas Gadjah Mada-Dr. Sardjito General Hospital approved the study protocol. After detailed explanation, informed consent was obtained from each patient prior to examination.

\section{Statistical analysis}

Statistical analysis was performed using the SPSS 23.0 for Windows software. Data were expressed as the mean \pm SD. Normality of all data samples was first confirmed by the Kolmogorov-Smirnov test. Differences in research subject characteristics were analyzed using the chi-square test for categorical data and unpaired t-test for numerical data if the distribution was normal or Mann-Whitney test if the distribution was abnormal. The mean MPC values was analyzed using the unpaired t-test, and the proportion between groups was analyzed using the chi-square test. To compare mean MPC between more than two groups, ANOVA test was performed. 
Pearson correlation test was used for analyzing relationships between MPC and other parameters.

\section{Results}

Demographic characteristics are listed in Table 1. There were mostly female subjects in both groups; mean age was $58.96 \pm 7.66$ years and $55.65 \pm 9.10$ years for the NPDR and PDR groups, respectively. There was a significantly higher mean systolic blood pressure in the PDR group.

Table 1. Characteristics of the study subjects

\begin{tabular}{|c|c|c|c|}
\hline Variable & NPDR & PDR & $p$ \\
\hline $\mathrm{N}(\%)$ & $51(71.83 \%)$ & $20(28.17 \%)$ & $<0.001^{\star}$ \\
\hline $\begin{array}{l}\text { Gender, n (\%) } \\
\text { Male } \\
\text { Female }\end{array}$ & $\begin{array}{l}14(27.5 \%) \\
37(72.5 \%)\end{array}$ & $\begin{array}{l}6(30 \%) \\
14(70 \%)\end{array}$ & 0.830 \\
\hline Age, yr ( \pm SD) & $58.96( \pm 7.66)$ & $55.65( \pm 9.10)$ & 0.125 \\
\hline BMI (kg/m2) & $24.73( \pm 4.17)$ & $\begin{array}{l}23.82 \\
( \pm 2.94) \\
\end{array}$ & 0.378 \\
\hline DM duration, yr ( \pm SD) & $7.66( \pm 8.12)$ & $10.3( \pm 6.37)$ & 0.196 \\
\hline Visual acuity (logMar) & $0.82( \pm 0.52)$ & $1.09( \pm 0.67)$ & 0.088 \\
\hline $\begin{array}{l}\text { DR grade: } \\
\text { Mild NPDR } \\
\text { Moderate NPDR } \\
\text { Severe NPDR } \\
\text { Very severe NPDR } \\
\text { Early PDR } \\
\text { High-risk PDR } \\
\text { Advanced PDR } \\
\end{array}$ & $\begin{array}{l}13(18.31 \%) \\
20(28.17 \%) \\
17(23.94 \%) \\
1(1.41 \%)\end{array}$ & $\begin{array}{l}4(5.63 \%) \\
11(15.49 \%) \\
5(7.04 \%) \\
\end{array}$ & \\
\hline HbA1c, \% ( \pm SD) & $9.14( \pm 2.38)$ & $8.37( \pm 2.30)$ & 0.239 \\
\hline $\mathrm{SBP}(\mathrm{mmHg})$ & $\begin{array}{l}139.24 \\
( \pm 21.37)\end{array}$ & $\begin{array}{l}151.80 \\
( \pm 20.59)\end{array}$ & $0.028^{*}$ \\
\hline
\end{tabular}

NPDR: non-proliferative diabetic retinopathy; PDR: proliferative diabetic retinopathy: $\mathrm{N}(\%)$ : numbers (percentage); BMI: body mass index; DM: diabetes mellitus, SBP: systolic blood presssure 
Table 2 provides an overview of total MPC values in subjects with DR and betweeen genders. It also shows the differences in mean MPC between NPDR and PDR. Although the results were statistically significant, they were not clinically significant, as the difference between them was under $1.65 \mathrm{~g} / \mathrm{dl}$. Furthermore, 1.65 $\mathrm{g} / \mathrm{dl}$ is the difference in mean MPC between normal subjects and those with heart failure, since we did not discover any that correspond to NPDR and PDR at the time. This number was determined at the beginning of the sample calculation by using another MPC study on vasculopathy. ${ }^{11}$

Table 2. MPC values in subjects with diabetic retinopathy

\begin{tabular}{|l|l|l|l|l|l|l|}
\hline Variable & $\mathbf{n}$ & Mean (g/dl) & SD & \multicolumn{2}{|l|}{ MPC (g/dl) } & $\boldsymbol{p}$ \\
\cline { 4 - 7 } & & & & Minimum & Maximum & \\
\hline Male & 20 & 25.92 & \pm 1.67 & & & 0.176 \\
Female & 51 & 26.53 & \pm 1.70 & & & \\
Total $\dagger$ & 71 & 26.36 & \pm 1.71 & 22.70 & 29.70 & \\
NPDR & 51 & 26.69 & \pm 1.79 & & & $0.002^{*}$ \\
PDR & 20 & 25.52 & \pm 1.20 & & & \\
\hline
\end{tabular}

MPC: mean platelet component; NPDR: non-proliferative diabetic retinopathy; PDR: proliferative diabetic retinopathy; MPC: mean platelet component; †Total: MPC of NPDR and PDR subjects

${ }^{*} p<0.05$ : was considered statistically significant

Figure 1 further analyzes the relationship between DR severity and MPC values. There were significant differences in MPC values between mild NPDR groups and high-risk PDR $(p=0.015)$, and between moderate NPDR and high-risk PDR $(p=0.024)$.

Table 3 shows the proportion of MPC values under $26.7 \mathrm{~g} / \mathrm{dl}$, which is the MPC value on activated platelets. ${ }^{8}$ In this study, it was found that the PDR group had a significantly greater proportion of MPC values below $26.7 \mathrm{~g} / \mathrm{dl}$.

Table 4 displays the mean MPC for subjects with mild DR (mild and moderate NPDR) and severe DR (high-risk and advanced PDR); the difference was statistically and clinically significant $(p=0.001$, difference $>1.65 \mathrm{~g} / \mathrm{dl}$ ). It also presents the proportion test between those groups by using MPC value limit of $26.7 \mathrm{~g} / \mathrm{dl}$. The results showed that in the severe DR group (high-risk and advanced PDR) the proportion of MPC values below $26.7 \mathrm{~g} / \mathrm{dl}$ was significantly greater than in the mild DR group (mild and moderate NPDR).

This study also analyzed the correlations of MPC with age, DM duration, and systolic blood pressure using the Pearson method. A significant correlation was found between MPC levels and duration of DM ( $r=-0338 ; p=0.004)$, and between MPC and systolic blood pressure $(r=-0.241 ; p=0.043)$. There was no significant relationship between MPC and age $(r=-0.410 ; p=0.735)$. 


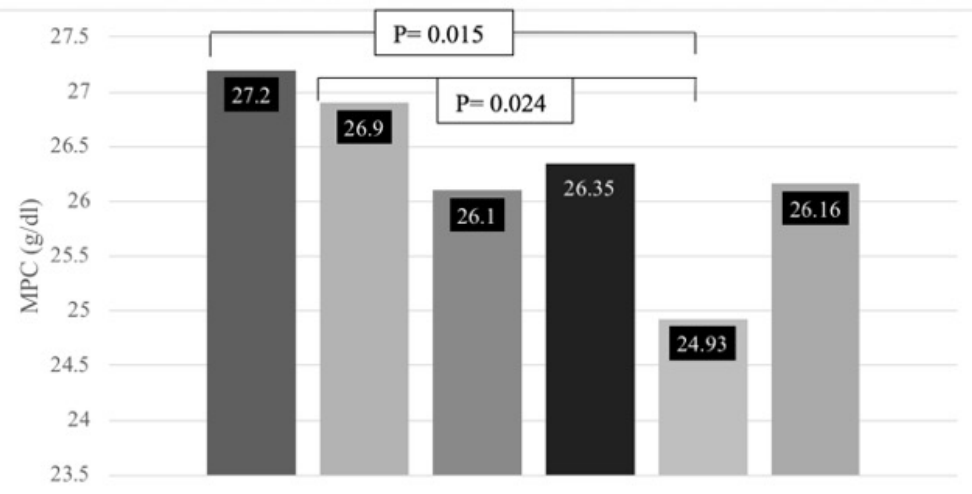

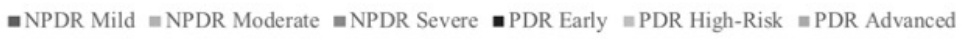

Fig. 1. The mean MPC values for each diabetic retinopathy severity.

Table 3. Proportion of MPC values $<26.7 \mathrm{~g} / \mathrm{dl}$ between NPDR and PDR

\begin{tabular}{|c|c|c|c|}
\hline Variable & NPDR $(n=51)$ & PDR $(n=20)$ & $p$ \\
\hline $\begin{array}{l}\text { MPC }<26.7 \\
\text { g/dl }\end{array}$ & $20(39.2 \%)$ & $18(90 \%)$ & \multirow{2}{*}{$<0.001^{\star}$} \\
\hline $\begin{array}{l}\text { MPC }>26.7 \\
\mathrm{~g} / \mathrm{dl}\end{array}$ & $31(60.8 \%)$ & $2(10 \%)$ & \\
\hline
\end{tabular}

NPDR: non-proliferative diabetic retinopathy; PDR: proliferative diabetic retinopathy; MPC: mean platelet component ${ }^{*} p<0.05$ was considered statistically significant

Table 4. Difference in mean MPC between mild DR (mild and moderate NPDR) and severe DR (high-risk and advanced PDR)

\begin{tabular}{|l|l|l|l|}
\hline Variable & $\begin{array}{l}\text { Mild and } \\
\text { moderate NPDR } \\
(\mathbf{n = 3 3 )}\end{array}$ & $\begin{array}{l}\text { High-risk and } \\
\text { advanced PDR } \\
(\mathbf{n = 1 6 )}\end{array}$ & $\boldsymbol{p}$ \\
$(\mathrm{g} / \mathrm{dl}),($ mean $\pm \mathrm{SD})$ & $27.01( \pm 1.64)$ & $25.31( \pm 1.22)$ & $0.001^{\star}$ \\
\hline $\mathrm{MPC}<26.7 \mathrm{~g} / \mathrm{dl}$ & $10(30.3 \%)$ & $15(93.8 \%)$ & \multirow{2}{*}{$<0.001^{\star}$} \\
\hline$M P C>26.7 \mathrm{~g} / \mathrm{dl}$ & $23(69.7 \%)$ & $1(6.2 \%)$ & \\
\hline
\end{tabular}

NPDR: non-proliferative diabetic retinopathy; PDR: proliferative diabetic retinopathy; MPC: mean platelet component ${ }^{*} p<0.05$ was considered statistically significant 


\section{Discussion}

In this study, there were more women than men in both groups. This has been supported by several prior studies showing that more women suffer from DM and greater DR severity. ${ }^{12-14}$ The mean age was higher in the NPDR group; this may be due to our sample size, which is smaller than that of previous studies. The mean age in the PDR group was similar to that in prior studies, with a range of 50-64 years. ${ }^{15}$ The BMI between the two groups was not statistically significant. This result may reflect the conflicting findings between high $\mathrm{BMI}$ as a risk factor ${ }^{16}$ or even protective ${ }^{17}$ for DR.

The average duration of DM was higher in the PDR group, similar to Kajiwara et al. ${ }^{14}$ This is explained by the fact that greater DM duration tends to cause greater microvascular damage. Visual acuity between the two groups was not statistically significant, but a lower average was obtained in the PDR group, which was similar to previous studies. ${ }^{18} \mathrm{HbA} 1 \mathrm{c}$ level was not statistically significant, which may be due to more strict sugar control in severe DR groups. The examination of systolic blood pressure shows a significantly higher result in the PDR group, in accordance with the theory that increase in pressure triggers deterioration of DR. ${ }^{19}$

This study evaluated the characteristics of MPC in all subjects to provide more data regarding MPC in DR patients. The mean obtained was $26.36 \mathrm{~g} / \mathrm{dl}$, illustrating that most subjects experience platelet activation, represented by MPC values below $26.7 \mathrm{~g} / \mathrm{dl} .{ }^{8}$ Activated platelets release granules, causing their density to lessen, which results in decreasing MPC value. ${ }^{10}$ The mean MPC between NPDR and PDR was found to be statistically significant, but not clinically significant because the difference was less than $1.65 \mathrm{~g} / \mathrm{dl}$. This limit was determined in the sample calculation by using other vasculopathic abnormalities ${ }^{11}$ as a reference since there is no MPC-related research with DR that can represent it. Considering those results, this study further examined the difference in MPC values between DR severity (Fig. 1) and obtained statistically and clinically significant results between mild NPDR and high-risk PDR, and between moderate NPDR and high-risk PDR. This shows there is higher platelet activation in high-risk PDR. This can be caused by neovascularization triggered by retinal ischemia. ${ }^{20}$ In these conditions, abnormal blood vessels grow and are easily damaged, leading to more platelets being activated. Activated platelets release intracellular substances stored in alpha and dense granules to begin the process of hemostasis. ${ }^{21}$ One component contained within the granule is vascular endothelial growth factor (VEGF), which spurs neovascularisation, thus worsening DR. ${ }^{22,23}$ On the other hand, in the advanced PDR group there was no significant difference from mild or moderate NPDR; this could be due to the complete neovascularisation process and regression. ${ }^{24}$ Another possibility is the use of long-acting antidiabetic drugs in advanced PDR subjects that are likely to affect the platelet activation index. ${ }^{25}$ However, there is no evidence to prove a relationship with MPC. When compared with the NPDR group, the number of activated platelets in the PDR group 
had a greater proportion (Table 3), in agreement with the previous theory. ${ }^{20,26}$

Based on the results, this study also conducted a comparison of MPC values in mild DR (defined as mild and moderate NPDR) with severe DR (defined as high-risk and advanced PDR). The results are listed in Table 4, which shows significant difference on the mean MPC and the proportion of activated platelets. The mean MPC value is significantly lower in severe DR, which is consistent with the theory that worse DR has more activated platelets. ${ }^{27,28}$

In addition to MPC values between NPDR and PDR, this study also analyzed MPC based on gender, as well as the association of MPC with age, DM duration, and systolic blood pressure. The findings in Table 2 showed that there was no statistically significant difference in MPC between men and women, which is in accordance with previous studies on platelet parameters. ${ }^{29}$ In the correlation test with age, no statistically significant results were obtained, although a negative correlation was found, similar to a previous study on the Korean population..$^{30}$ As for the duration of DM and systolic blood pressure, there was a significantly negative correlation with MPC; this indicates that the longer a person has DM or the higher the systolic blood pressure, the lower the MPC value. This is because the duration of prolonged DM will exacerbate vasculopathy in $\mathrm{DR}^{31}$ and high systolic blood pressure will result in endothelial dysfunction. ${ }^{32}$

The main limitation of the present study is its retrospective nature, which cannot establish a causal relationship between MPC and PDR development. Furthermore, the grouping of subjects into NPDR or PDR was based only on the assessment of neovascularization through fundus photographs. Although fundus photographs have a sensitivity between $88.9 \%$ and $97.7 \%$, and a specificity between $98.9 \%$ and $100 \%$ to detect $D R,{ }^{33}$ we did not use a seven-field stereo fundus, which could have led to underestimation of the number of PDR subjects. ${ }^{34}$

In summary, PDR subjects have lower MPC values compared with NPDR. This distinction grew when a comparison was made between the lower and higher end of the disease spectrum. These data suggest that MPC has a role in disease progression on subjects with NPDR. The authors suggest that further studies are needed to observe whether MPC values can be used to predict the progression of NPDR into PDR, thus allowing earlier management.

\section{Declarations}

\section{Ethics approval and informed consent}

The study followed the tenets of the Declaration of Helsinki. The Ethics Committee of the Faculty of Medicine, Universitas Gadjah Mada-Dr. Sardjito General Hospital approved the study protocol. After detailed explanation, informed consent was obtained from each patient prior to examination. 


\section{Competing interests}

None to declare.

\section{Funding}

None to declare.

\section{Acknowledgements}

None to declare.

\section{References}

1. Lee R, Wong TY, Sabanayagam C. Epidemiology of diabetic retinopathy, diabetic macular edema and related vision loss. Eye Vis. 2015;2:17.

2. Zheng Y, He M, Congdon N. The worldwide epidemic of diabetic retinopathy. Indian J Ophthalmol. 2012;60(5):428.

3. Hajar S, Hazmi A Al, Wasli M, Mousa A, Rabiu M. Prevalence and causes of blindness and diabetic retinopathy in southern Saudi Arabia. Saudi Med J. 2015;36(4):449-55.

4. Liu Y, Song Y, Tao L, et al. Prevalence of diabetic retinopathy among 13473 patients with diabetes mellitus in China: a cross-sectional epidemiological survey in six provinces. BMJ Open. 2017;7(1):e013199.

5. Zhong Z-L, Han M, Chen S. Risk factors associated with retinal neovascularization of diabetic retinopathy in type 2 diabetes mellitus. Int J Ophthalmol. 2011;4(2):182-5.

6. Schneider DJ. Factors Contributing to Increased Platelet Reactivity in People With Diabetes. Diabetes Care. 2009;32(4):525-7.

7. Vinik Al, Erbas T, Park TS, Nolan R, Pittenger GL. Platelet dysfunction in type 2 diabetes. Diabetes Care [Internet]. 2001;24(8):1476-85.

8. Bae SH, Lee J, Roh KH, Kim J. platelets activation in Patients with Diabetic Retinopathy. Korean J Ophthalmol. 2003;17:140-4.

9. Solomon SD, Chew E, Duh EJ, et al. Diabetic Retinopathy: A Position Statement by the American Diabetes Association. Diabetes Care. 2017;40(3):412-8.

10. Rechner AR. Platelet function testing in clinical diagnostics. Vol. 31, Hamostaseologie. 2011. p. 79-87.

11. Chung I, Choudhury A, Lip GYH. Platelet activation in acute, decompensated congestive heart failure. J Throm Res. 2007;120(5):709-13.

12. Tian H, Song G, Xie H, Zhang H, Tuomilehto J, Hu G. Prevalence of diabetes and impaired fasting glucose among 769792 rural Chinese adults. Diabetes Res Clin Pr. 2009;84(3):273-8.

13. Nguyen QM, Xu J-H, Chen W, Srinivasan SR, Berenson GS. Correlates of Age Onset of Type 2 Diabetes Among Relatively Young Black and White Adults in a Community: The Bogalusa Heart Study. Diabetes Care. 2012;35(6):1341-6.

14. Kajiwara A, Miyagawa H, Saruwatari J, Kita A, Sakata M. Gender differences in the incidence and progression of diabetic retinopathy among Japanese patients with type 2 diabetes mellitus: A clinic-based retrospective longitudinal study. Diabetes Res Clin Pr. 2014;103(3):e7-10. 
15. Kempen JH, O'Colmain BJ, Leske MC, et al. The prevalence of diabetic retinopathy among adults in the United States. Arch Ophthalmol. 2004;122(4):552-63.

16. Kaštelan S, Tomić M, Gverović Antunica A, Ljubić S, Salopek Rabatić J, Karabatić M. Body Mass Index: A Risk Factor for Retinopathy in Type 2 Diabetic Patients. Mediat Inflamm. 2013;2013.

17. Lu J, Hou X, Zhang L, et al. Association between body mass index and diabetic retinopathy in Chinese patients with type 2 diabetes. Acta Diabetol. 2015;52(4):701-8.

18. Klein R, Klein BEK, Moss SE. Visual Impairment in Diabetes. Ophthalmology. 1984;91(1):1-9.

19. Adler AI, Stratton IM, Neil HAW, et al. Association of systolic blood pressure with macrovascular and microvascular complications of type 2 diabetes (UKPDS 36): prospective observational study. BMJ. 2000;321:412-9.

20. Ciulla TA, Amador AG, Zinman B. Diabetic retinopathy and diabetic macular edema: Pathophysiology, screening, and novel therapies. Diabetes Care. 2003;26(9):2653-64.

21. Ghoshal K, Bhattacharyya M. Overview of platelet physiology: Its hemostatic and nonhemostatic role in disease pathogenesis. Sci World J. 2014;2014.

22. Ferroni P, Basili S, Falco A, Davì G. Platelet activation in type 2 diabetes mellitus. J Thromb Haemost. 2004;2(8):1282-91.

23. Fitch-Tewfik JL, Flaumenhaft R. Platelet granule exocytosis: A comparison with chromaffin cells. Front Endocrinol. 2013;4(JUN):1-11.

24. Singh R, Ramasamy K, Abraham C, Gupta V, Gupta A. Diabetic retinopathy: An update. Indian J Ophthalmol. 2008;56(3):179-88.

25. Dolasik I, Sener SY, Celebi K, Aydin ZM, Korkmaz U, Canturk Z. The effect of metformin on mean platelet volume in dıabetıc patients. Platelets. 2012;24(2):118-21.

26. Caldwell RB, Bartoli M, Behzadian MA, et al. Vascular endothelial growth factor and diabetic retinopathy: Pathophysiological mechanisms and treatment perspectives. Diabetes Metab Res Rev. 2003;19(6):442-55.

27. Walsh TG, Metharom P, Berndt MC. The functional role of platelets in the regulation of angiogenesis. Platelets. 2014;7104(October):1-13.

28. Araz Gungor A, Gursoy G, Gungor F, Bayram SM, Atalay E. The relationship of mean platelet volume with microalbuminuriain type 2 diabetic patients. Turk J Med Sci. 2016;46(July 2012):251-8.

29. Butkiewicz AM, Kemona H, Dymicka-Piekarska V, Matowicka-Karna J, Radziwon P, Lipska A. Platelet count, mean platelet volume and thrombocytopoietic indices in healthy women and men. J Throm Res. 2006;118(2):199-204.

30. Kim MJ, Park PW, Seo YH, et al. Reference intervals for platelet parameters in Korean adults using ADVIA 2120. Ann Lab Med. 2013;33(5):364-6.

31. Fong DS, Aiello L, Gardner TW, et al. Retinopathy in Diabetes. Diabetes Care. 2004;27(SUPPL. 1).

32. Soares. Hemostatic changes in patients with type 2 diabetes mellitus. 2010; Rev Bras Hematol Hemoter. 2010;32(6):482-8.

33. Saari JM, Summanen P, Kivela T, Matti K. Sensitivity and specificity of digital retinal images in grading diabetic retinopathy. Acta Ophthalmol Scand. 2004;82:126-30.

34. Møller F, Hansen M, Sjølie AK. Is one 60 degrees fundus photograph sufficient for screening of proliferative diabetic retinopathy? Diabetes Care. 2001;24(12):2083-5. 